\title{
SWEET BUSINESS: QUANTIFYING THE VALUE ADDED IN THE BRITISH COLONIAL SUGAR TRADE IN THE $18^{\mathrm{TH}}$ CENTURY*
}

KLAS RÖNNBÄCK

University of Gothenburg ${ }^{\text {a }}$

\begin{abstract}
There has been a lot of research into the economic contribution of the periphery to European economic development during the early modern era. This paper estimates quantitatively the value added in the sugar trade from the Caribbean to Britain in the $18^{\text {th }}$ century. The trade generated a value equivalent to around 1 per cent of British gross domestic product (GDP) by the early $18^{\text {th }}$ century, growing to 4 per cent of GDP a century later. The results show that the sugar trade constituted a dynamic and rapidly growing part of the British economy, most importantly the tertiary sector.
\end{abstract}

Keywords: colonialism, slavery, sugar, value added, Britain

JEL Code: N16, N56, N76

* Received 11 November 2013. Accepted 22 April 2014. The author would like to thank Gregory Clark and David Beck Ryden for generously sharing their data with me. The author would also like to thank three anonymous reviewers, as well as Herbert Klein, Antonio Tena-Junguito, Franklin Knight and other participants of the Second Conference of the Caribbean Economic History Association, for many constructive comments on a presentation of a previous draft of this paper.

${ }^{a}$ Economic History, Box 720, SE-405 30 Sweden. klas.ronnback@econhist.gu.se 


\section{RESUMEN}

La contribución económica de la periferia hacia el desarrollo económico de Europa durante la Edad Moderna se ha investigado mucho. Este trabajo estima cuantitativamente el valor agregado en el comercio de azúcar desde el Caribe a Gran Bretaña en el siglo XVIII. El comercio generó un valor equivalente a alrededor del uno por ciento del PIB británico a principios del siglo XVIII, con un aumento de hasta el cuatro por ciento del PIB un siglo más tarde. Los resultados muestran que el comercio del azúcar constituyó un sector dinámico y de rápido crecimiento en la economía británica, más importante en el sector terciario.

Palabras claves: colonialismo, esclavitud, azúcar, valor añadido, Gran Bretaña

\section{INTRODUCTION}

Recent years have seen the return of a debate about what economic contribution the "periphery" has made to economic progress in Europe, for example, during the early modern era. The controversy was, to a large extent, initiated by the Trinidadian historian Eric Williams who, in his classic book Capitalism and Slavery (1944), argued that the Atlantic triangular trade, and more especially the slave trade, made an «enormous contribution» to economic development in Britain, and its Industrial Revolution in particular. This contribution came primarily from the profits from the slave trade, which according to Williams were largely re-invested in British industrial development (Williams 1964 [1944], p. 105). Many scholars have since contributed to a discussion of this Williams Thesis. In what is perhaps the most often cited article on the topic, Patrick O'Brien criticised the Williams Thesis. In his article, O'Brien argued — based on some rough estimates and assumptions - that the aggregated profits from the slave trade contributed, at most, to 15 per cent of gross investments in Britain. This, he argued, was too small to make any substantial contribution to the British economy. He therefore arrived at the conclusion that the periphery's contribution to Europe's economic development was peripheral (see also Engerman 1972; Engerman and Solow, 1987; O’Brien 1982; Solow and Engerman 1987; Solow 1991; Morgan 2000 for other key contributions). In recent years, O'Brien has, however, found it necessary to revise some of his own previous conclusions. Commenting on his previous study, O'Brien now argues that the contribution to British investments at the time was hardly negligible, and therefore draws the conclusion that the contribution of the "periphery» was not that peripheral after all (O'Brien 2006). 
Many of the previous contributions in this field have thus focused on one part of this trade: the economic profits from the slave trade in particular, and the extent to which they contributed to Britain's industrial development (Engerman 1972; O'Brien 1982; Solow and Engerman 1987; Solow 1991; Morgan 2000; Inikori 2002; Daudin 2004; Daudin 2005). Joseph Inikori has, however, recently argued that the profits from the slave trade or even from the plantation complex were not the only - and perhaps not even the primary - means by which early modern Britain gained economically from possessing colonies in the Americas and the Caribbean. Instead, the economic gains from the possession of colonies, Inikori argues, must be analysed as the total economic activity generated in a host of sectors of the economy - including shipping and shipbuilding, insurance, financial institutions and the manufacturing of goods sold in the colonial markets (see also Sheridan 1994, Ch. 19.8; Morgan 2000; Inikori 2002). In his book, Joseph Inikori expressed the hope that his conclusions would provoke further research, particularly concerning the value of Atlantic commerce (Inikori 2002, p. xix).

The topic received further attention when Ronald Findley and Kevin O'Rourke, in their work Power and Plenty, argued that the Williams Thesis could not necessarily be dismissed as easily as some previous scholars had argued. Importantly, however, they argued that the absolute levels of profits, analysed in static terms, might not be as important as the extent to which an economic activity contributed to a dynamic development (Findlay and O'Rourke 2007, pp. 334-337). This seeming revival of the Williams Thesis, in turn, has led to renewed criticism from scholars such as Deirdre McCloskey, returning to many of the previous studies for a critique of the Williams Thesis (McCloskey 2010, Ch. 26). More recently still, C. Knick Harley has, largely on theoretical grounds, argued that the key contributions any colonies made to Britain's economy were as markets for British manufacturers. For this reason, Harley claims, the most important colonies for Britain were to be found on the North American mainland, rather than in the West Indies as Eric Williams claimed (Harley 2013).

\section{AIM OF THIS STUDY}

In this paper, I attempt to contribute to this field of research by focusing on the sugar commodity chain. This part of the triangular trade has not been examined as closely in this context as the slave trade. The paper will furthermore not focus on profits per se, as the majority of previous studies in the field have done, but will attempt to broaden the discussion beyond the issue of profits alone, in line with Joseph Inikori's point of departure. The aim of this paper is therefore to attempt to quantify the economic activity by 
estimating the value added in the sugar trade. The research questions of the paper are:

1) How large was the value added in the sugar commodity chain, relative to the British national economy?

2) Where and by whom was value added in the early modern sugar commodity chain?

The outstanding impact that sugar in particular had upon the development of the early modern American economy in general, and the Caribbean economy in particular - from the so-called "sugar revolution", and for a long time afterwards - is well known and quite extensively researched (for some notable contributions see Dunn 1972; McCusker and Menard 1985, Ch. 7; Watts 1987; Sheridan 1994; Stinchcombe 1995, Ch. 4; Curtin 1998; Higman 2000; Schwartz 2004; Menard 2006; Moya Pons 2007, Ch. 8). Less research has been devoted to the trade in sugar once the commodity left the Caribbean. In particular, very little research has centred on the study of sugar factories or refineries in Europe. Some scholars have discussed this sector from social, political and cultural perspectives (Deerr 1949, Ch. 28; Stern 1954; Woloson 2002). As far as this author is aware, the only previous quantitative research into the economic history of sugar refining comes from research on French and Danish sources (Sveistrup and Willerslev 1945; Stein 1988). The contribution of this particular paper is to attempt to follow the whole of the early modern sugar commodity chain, from production in the Americas to consumption in Europe, estimating the value added at the various links in the chain.

\section{METHOD AND SOURCES}

The paper will make use of the concept of commodity chains, defined by Terence Hopkins and Immanuel Wallerstein as «a network of labour and production processes whose end result is a finished commodity». Studying commodity chains, they argue, is a means of analysing a complex division of labour across frontiers and borders, thereby enabling a study of the «transnational interdependence of productive activities» (Hopkins and Wallerstein 1986, pp. 159-160). The concept has been used for this purpose in many other studies of commodity production, for example, in a number of studies of Latin America's contribution to the building of the modern world economy (see, e.g. Topik et al. 2006). Studying the value added in the sugar commodity chain is motivated by the aim of this paper to analyse economic activity by examining the slave-based plantation complex, rather than focusing on profits alone. By studying the value added at various stages in the commodity chain it is possible to explore the transnational interdependence 
of the early modern sugar trade. The distribution of value added is not only a reflection of the productivity at various stages of the chain, but also a reflection of the economic rents that can be appropriated, for example, through government regulations or through participating in links with little or no competition between different agents.

The quantitative data used in this paper come from research done by other scholars, who studied sources in various different archives. There are three series of data of central importance to this study: the local, farmgate price of muscovado sugar in Jamaica, the wholesale price of similar sugar in England and the retail price of various varieties of refined sugar in England. Even though most sugar produced was exported to Europe, some of the produce was sold on local markets (Higman 1996). David Beck Ryden has recently assembled data on the farmgate price of muscovado sugar in Jamaica during the second half of the $18^{\text {th }}$ century (Ryden 2009, table A7). There are also three different series of data assembled on the price of muscovado sugar in Britain: two series from London and one from Bristol (McCusker 1970, table E-44, p. 1143; Morgan 1993, table 7.10; Sheridan 1994, appendix V, p. 496f). The first two series cover the period until the American Revolution, whereas the third series of data continues until the year 1800 . The Bristol prices are possibly somewhat higher than the prices sugar was sold for in London, perhaps due to a lower degree of competition (Morgan 1993, p. 211). Splicing the three series of data together might therefore lead to a problem of upward bias in the wholesale price series at the end of the period, which needs to be taken into consideration when interpreting any results. The retail prices of a number of varieties of sugar in England, finally, have been assembled from various sources by Gregory Clark (data underlying Clark 2005). A further discussion on this, and how a weighted average price for refined sugar is calculated, is reported in Appendix B.

\section{THE COLONIAL SUGAR COMMODITY CHAIN}

The general outlines of the early modern commodity chain for sugar are by now quite well known (see, e.g. Mintz 1985; Galloway 1989; Sheridan 1994). Before the $19^{\text {th }}$-century introduction of beet sugar, sugar was extracted from the sugar cane. Sugar cane grows best in tropical or subtropical climates. The Caribbean islands were, from that perspective, ideal for the growing of sugar cane. The actual work of raising the sugar cane came to be undertaken almost exclusively by slaves of African origin, under the supervision of European owners or overseers. Early modern European mercantilist policies stipulated that the manufacturing of raw materials should be undertaken in the metropolises of the European colonial powers. As harvested cane decomposes quite rapidly, however, sugar cane must be 
processed into raw sugar within a few days of the harvest. This biological trait of the crop meant that the export of unprocessed sugar cane was impossible. Planters in the Caribbean were therefore allowed to produce raw sugar, and in time also a semi-refined variety called clayed sugar, locally in the Caribbean. The raw sugar was then exported by merchant capitalists, or by the planters themselves, requiring the services (e.g. freight and insurance) of a number of agents. Over the $18^{\text {th }}$ century, planters increasingly came to sell their produce themselves in Britain, with the assistance of commissioned agents, rather than selling the goods to merchants in Jamaica (as had been the most common practice previously). Duties would have to be paid on the imports of sugar. These duties depended on the country of origin (commonly distinguishing between colonial and foreign sugar) and the stage of refinement of the imported sugar (commonly escalating tariffs). Once in Europe, the raw muscovado sugar was sold to sugar factories or refineries, and further refined into a number of varieties and qualities ready for the consumer: white sugar, powdered sugar, canary sugar and so on. The final consumers could then purchase the refined sugar from retailers, such as general stores.

Many British planters were involved not only in the growing of cane and the production of raw sugar, but also in the transatlantic trade in the output (Curtin 1998, pp. 140-141). While some planters in the sugar commodity chain might have invested their own money in a plantation, most planters were really investing borrowed capital. A large part of the value added at the plantation was, therefore, appropriated by the creditors rather than by the planter (Price 1991; Sheridan 1994, Ch. 12).

Figure 1 shows the price of sugar at the three stages in the commodity chain for which price data are available: at the plantation, at the stage of wholesaling and at the stage of retailing.

As is obvious from the figure, the value added and profits made at the plantation stage in Jamaica only constituted a small, albeit quite stable, share (around one-third throughout the period) of the total value added in the whole sugar commodity chain. The second stage of the commodity chain including the shipping and wholesaling of the sugar - constituted the largest share (around 40 per cent on average for the whole period) of the value added in the commodity chain. At the third stage of the commodity chain, retail prices seem to follow wholesale prices very closely, with a 1-year time lag. The time lag might at least be partly due to the fact that it took some time to refine and distribute the sugar in England, so that any price changes at the stage of wholesaling only showed up in the retail stage some time later.

\section{THE SUGAR TRADE AND THE BRITISH NATIONAL ECONOMY}

Figure 2 shows how important the sugar trade was to the British economy. In the figure, the value added by the sugar trade is shown relative to British 
FIGURE 1

THE PRICE OF SUGAR (RAW/REFINED) AT THREE STAGES IN THE COMMODITY CHAIN (SHILLINGS STERLING/KG, DEFLATED), 1700-1807

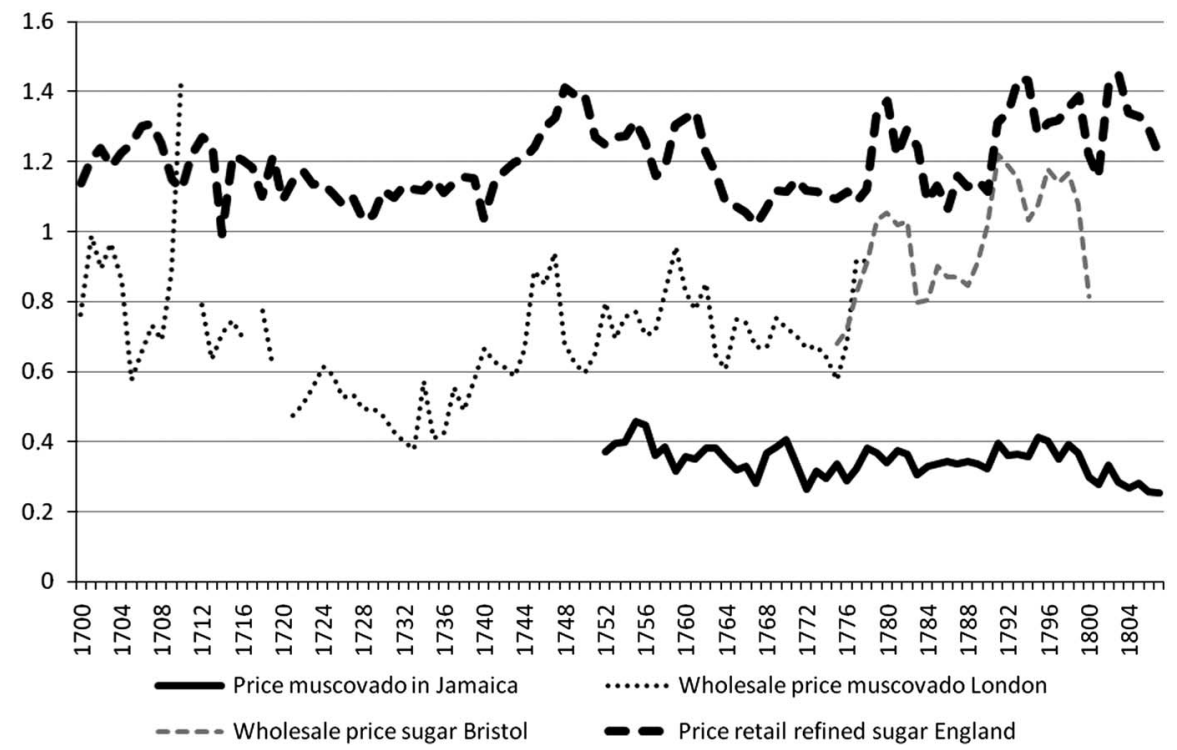

Sources: Price in Jamaica from Ryden (2009, table A7); wholesale price London from McCusker (1970, table E-44, p. 1143); wholesale price Bristol from Morgan (1993, table 7.10); retail price of refined sugar from data set underlying Clark (2005). Price deflator $(1,700=100)$ from database underlying Broadberry et al. (2011).

Note: On the weighting of the retail price, see Appendix B.

gross domestic product (GDP). The series showing the value of the retained sugar imports is calculated using the prices for refined sugar, multiplied by the quantities of retained imports. The value of the re-exported sugar is calculated in two ways: first a minimum estimate, using prices at the stage of wholesaling in Britain, thus assuming that most of the sugar re-exported was unrefined; second a maximum estimate, using the price of refined sugar instead. Since Britain's comparative advantage at this time lay in capitalintensive manufacturing and processing, a large share of the re-exports was probably refined. There are gaps in the series after 1776 owing to missing data on the quantities of sugar imported and re-exported. It is assumed here that the re-exports were largely undertaken by traders of other nationalities, in order not to overestimate any contribution that the trade made to British GDP.

The sugar trade targeting the domestic market generated an economic value of $\sim 1$ per cent of British GDP by the early $18^{\text {th }}$ century, growing to around 4 per cent by the 1770s. After the outbreak of the American 
FIGURE 2

THE SUGAR TRADE'S SHARE OF BRITISH GDP, 1700-1807

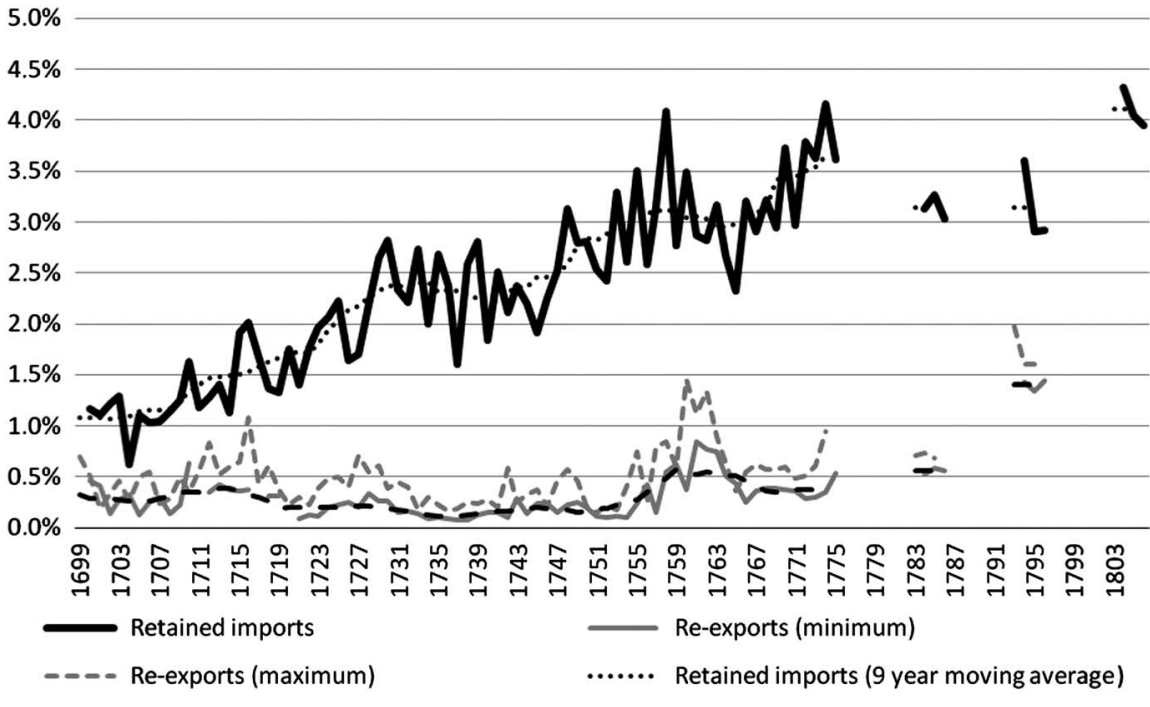

- Re-exports, min (9 year moving average)

Sources: Nominal GDP from database underlying Broadberry et al. (2011); sugar imports from Sheridan (1994, table IV) and Davis (1979, table 27); price of muscovado sugar for re-exports (see Figure 1); weighted retail price of refined sugar for retained imports, see Appendix B.

Revolutionary War, the sugar trade seems to have experienced economic hardships, contributing to a decreasing share of British GDP. Re-exports accounted for a fairly negligible share of British economic activity, except during war years when the value created could rise to around 1 to 2 per cent of national GDP. If any sugar was smuggled into Britain, and therefore omitted from the official trade accounts, it would not be included in the calculations above. The estimates must therefore be considered as a lowerbound estimate of the actual value.

\section{DISAGGREGATING THE SUGAR COMMODITY CHAIN}

The data presented in Figure 1 can to some extent be disaggregated, showing the share of value added by various agents involved in the sugar commodity chain. The details of this process are reported in the Appendix to this paper. Because of a lack of complete time series of data for some variables (discussed further in the Appendix), all disaggregated data must be interpreted with some caution. 
FIGURE 3

FACTOR INCOMES AT PLANTATION STAGE IN JAMAICA, 1752-1807 (SHILLINGS/ KG OF SUGAR PRODUCED, DEFLATED)

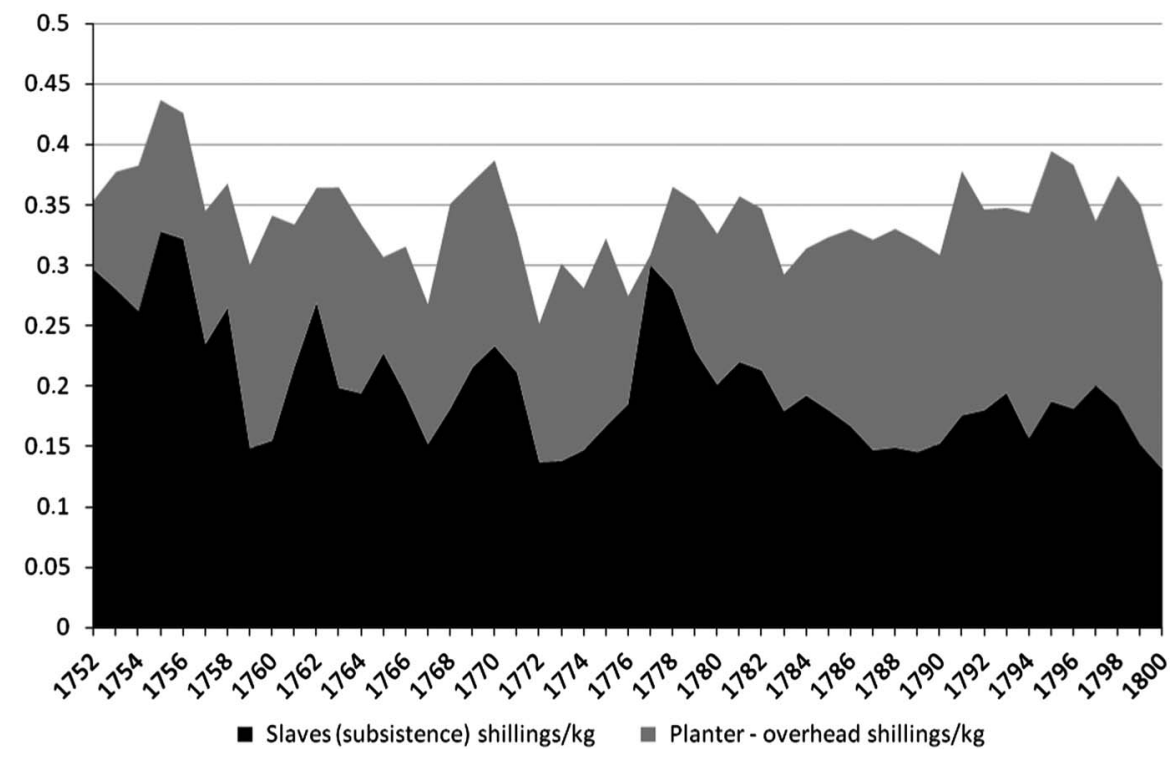

Sources: Subsistence cost from Ward (1978); productivity figures from Ryden (2009, figure 9.2). Price deflator $(1,752=100)$ from database underlying Broadberry et al. $(2011)$.

Note: See text in Appendix A1 for a detailed description.

Figure 3 shows the cost of subsistence for slaves and the gross surplus value created by slaves (per kilogram of sugar produced, in order to show the value added at the plantation stage). The rate of surplus value extracted increased over the period, from around 40 per cent in the 1750 s, to around 100 per cent in the 1790s. This is largely owing to a rise in the productivity of slaves over the period: Ryden's figures indicate that the amount of sugar produced per slave increased dramatically over the second half of the $18^{\text {th }}$ century. Combined with rising prices for the sugar sold, the gross revenue of the planters increased substantially.

Figure 4 shows the value added by a number of agents at the wholesale stage of the commodity chain. The share of value added by these agents seems to have grown over the period. There are a number of factors contributing to this growth in the share of value added. First, transport costs increased in wartime, in tandem with insurance costs - as would be expected. These costs were reduced once peace arrived, but the second half of the $18^{\text {th }}$ century saw many years of war. Second, sugar duties were increased over the period to the extent that the share of value added 
FIGURE 4

FACTOR INCOMES AT WHOLESALE STAGE IN ENGLAND, 1752-1800 (SHILLINGS/KG, DEFLATED)

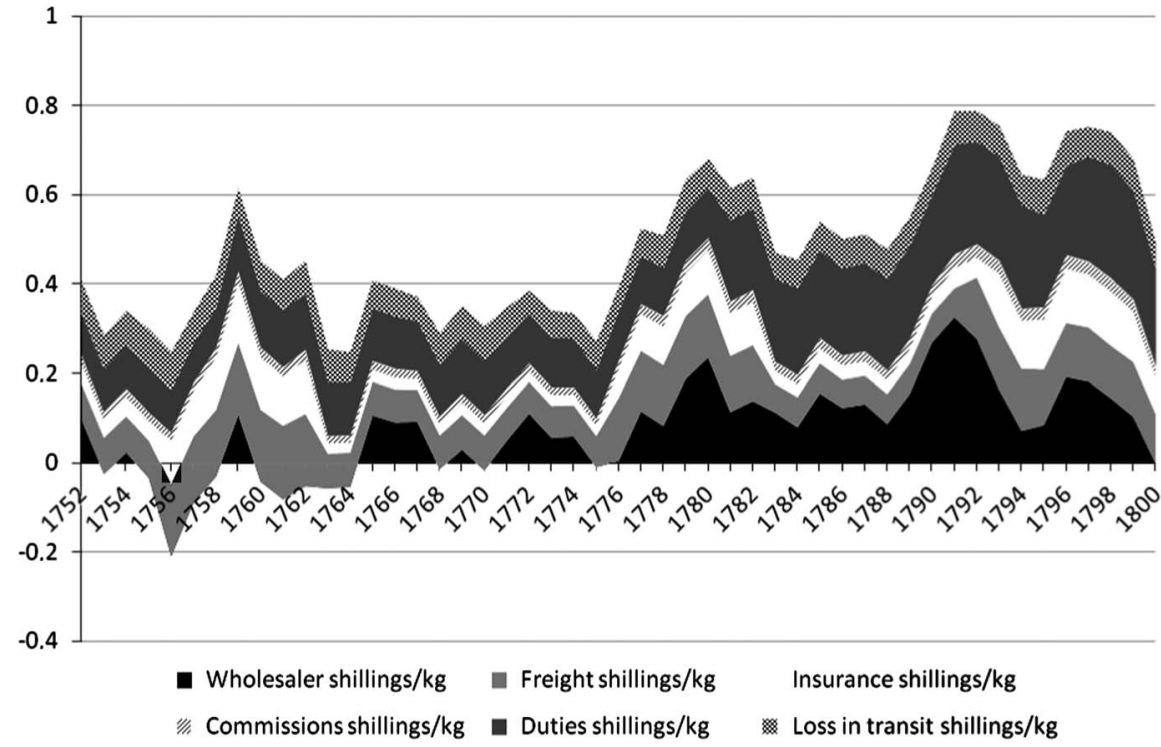

Sources: Figures for transport costs from Ward (1978, tables 1-2, p. 199); losses from Sheridan (1994, p. 44); McCusker (1970, pp. 138-142); duties from Deerr (1949, vol. II, p. 430). Price deflator $(1,752=100)$ from database underlying Broadberry et al. (2011).

Note: See text in Appendix A2 for a detailed description.

appropriated by the government more than doubled, from 8 to 18 per cent of the value added in the commodity chain. Third, the traders/wholesalers might have appropriated an increasingly larger share of the value added, rising from 0 (or even net losses) in the first years of the period to around 10 to 15 per cent of the value added by the end of the period.

Because of a lack of data, it has not so far been possible to disaggregate the third stage of the commodity chain, the stage of refining and retailing, with any degree of certainty. As is discussed in Appendix A3, however, available data indicate that the share of the added value that went to the capital owners might have been quite high at this stage.

Using the disaggregated data, with the data from the previous section of this paper, it is possible to divide the sugar trade's contribution by the total GDP according to the sector to which any such contributions belong primary, secondary or tertiary - and analyse the contribution that the sugar trade made to economic activity within each sector. This is done in Table 1 for the 1750s and 1790s. The benchmark periods are chosen because of availability of data on GDP dissaggregated by sector for these years. 
TABLE 1

THE SUGAR TRADE'S CONTRIBUTION TO BRITISH GDP, BY SECTOR, 1759 AND $1794 / 1796$

\begin{tabular}{|l|c|c|c|c|}
\hline & $\mathbf{1 7 5 9}$ & & $\mathbf{1 7 9 4 / 1 7 9 6}$ & \\
\hline & million $\mathbf{£}$ & $\begin{array}{c}\text { Share of } \\
\text { sector's GDP (\%) }\end{array}$ & million $\mathbf{£}$ & $\begin{array}{c}\text { Share of } \\
\text { sector's GDP (\%) }\end{array}$ \\
\hline Agriculture & 0.69 & 2.1 & 1.94 & 2.9 \\
\hline Slave subsistence & 0.34 & & 0.91 & \\
\hline Planter gross surplus & 0.35 & & 1.03 & \\
\hline Industry & 0.63 & 1.9 & 0.86 & 1.2 \\
\hline Refinery & 0.63 & & 0.86 & \\
\hline Services & 1.41 & 3.8 & 3.41 & 4.5 \\
\hline Freight & 0.37 & & 0.66 & \\
\hline Insurance & 0.31 & & 0.60 & \\
\hline Commissions & 0.05 & & 0.13 & \\
\hline Duties & 0.29 & & 1.10 & \\
\hline Wholesale & 0.25 & & 0.61 & \\
\hline Retailer & 0.14 & & 0.31 & \\
\hline Total & 2.86 & 2.8 & 6.60 & 3.1 \\
\hline
\end{tabular}

Notes: It is assumed here that the sectors' shares of total British GDP in 1794/1796 were similar to what they were in 1801. Broadberry et al. report no separate estimate of the public sector's share of GDP. Duties are therefore included under the heading of services, assuming that the revenue is used to provide government services.

Sources: See Figures 1 and 3-4 for data on the value added in the sugar trade. Sectoral shares of total British GDP from Broadberry et al. (2001, table 9).

As can be seen in Table 1, the sugar trade made its most important contribution to British economic activity in the service sector: around 4 to 5 per cent of the British service sector's GDP was directly associated with the sugar trade. This contribution might also have grown somewhat in importance, relative to the service sector's total economic activity. If credits provided to British planters had been included in the estimate, which was not possible in the current analysis, the service sector's gains from the sugar trade would have increased even further. The contribution to industrial development was, on the other hand, quite small, only 1 to 2 per cent of the sector's GDP, and seemingly diminished over the period. The estimates also show just how tempting smuggling must have been for the agents of the sugar trade. The share of added value appropriated by the government in the form of duties on sugar increased drastically over the $18^{\text {th }}$ century. As this 
share increased, incentives to smuggle sugar also increased. By the end of the $18^{\text {th }}$ century, the government appropriated a much larger share of the total added value in the form of duties, than, for example, the wholesalers did in their economic transactions. A trader could thus increase his profits many times over by successfully avoiding paying sugar duties.

\section{THE EXPLOITATION OF SLAVES IN THE COMMODITY CHAIN}

The disaggregated analysis of the value added in the sugar commodity chain shows how important the exploitation of slaves was for profits in the sugar trade. It has been argued that one of the central functions of the institution of slavery is to keep labour costs at a minimum, especially in a labour-scarce context (Domar 1970; Kolchin 1987). This was certainly the case for Caribbean sugar plantations. The subsistence costs for slave labour were, without a doubt, much lower than would have been needed to pay for any voluntary labour. Many recent studies have shown that the early modern real wages paid to an unskilled labourer in labour-rich regions of the world, such as India and China, might have gravitated towards the subsistence cost for a whole family (Allen 2009; Allen et al. 2011). The cost of free labour was even higher in labour-scarce areas of the world, such as the Americas. Recent estimates indicate that the wages paid to free labour in Latin America might have fluctuated around twice the cost of subsistence for a whole family, and at three to five times this subsistence cost for free labourers in North America (Allen et al. 2012). In contrast to the estimates of «welfare ratios», which thus calculate real wage relative to the cost of a subsistence basket for a whole family, the subsistence cost for slaves estimated by Ward, and used in this paper, is per slave. Free, unskilled labourers in labour-rich parts of the world were thus paid a wage some three times the amount of the subsistence cost for Caribbean slaves. In labour-scarce parts of the world such as Latin America, free unskilled labourers were paid wages equivalent to six to ten times the subsistence cost for the Caribbean slaves. C. Knick Harley has recently argued that sugar would have been much more expensive without access to slave labour, and probably too expensive to find many consumers willing to pay for its production (Harley 2013, p. 25). The results of the present paper show that this most certainly was true. Undoubtedly, without slavery, planters would not have needed the capital to purchase the labourers in the first place. It seems unreasonable to assume, however, that this would have compensated for the radically higher labour costs a free labour force would have required. Had the labour costs increased so as to match the wages paid to free labourers in Latin America (i.e. perhaps six to ten times higher), for example, this alone would have had substantial impacts on the whole sugar commodity chain. The sugar plantations of the Caribbean were also particularly dreaded places to work at, because of the high demographic 
cost, for example, due to the spread of epidemic diseases such as malaria (McNeill 2010). The higher labour costs of utilising free labour would either have translated into drastically reduced factor incomes for other agents (e.g. lower profits and/or returns on capital for planters or merchants), or into a considerable increase in the final price of the product (in turn probably leading to a decrease in the growth in demand for sugar). The brutal exploitation of African slaves was thus crucial for the revenues and profits of West Indian planters, merchants and refiners - as well as their creditors — in Britain.

\section{THE SUGAR TRADE AND BRITISH ECONOMIC DEVELOPMENT}

The economic activity generated in the British sugar trade was thus equivalent to a couple of per cent of total GDP at the time - around 4 to 5 per cent when the trade peaked at the end of the $18^{\text {th }}$ century. This takes us back to an old debate on whether a couple of per cent of GDP is much or little (Engerman 1972; O’Brien 1982; Solow and Engerman 1987; O’Brien 2006; McCloskey 2010). The interpretation of this author is that the evidence indicates that the colonial sugar trade's share of GDP constituted a most substantial share of British economic activity in the late $18^{\text {th }}$ century. The results of this study also show quite a dramatic growth in the sugar trade at least until the American Revolutionary War, even relative to the growth in GDP. The trade was thus not only able to keep up with the growing British economy during much of the $18^{\text {th }}$ century, but even grow in importance in relative terms. Imports grew more than fivefold in terms of volume, and more than tenfold in terms of nominal value (Sheridan 1994, tables IV and VIII). The sugar trade that targeted the domestic market grew from contributing around 1 per cent of total GDP by the early $18^{\text {th }}$ century, to around 4 per cent by the outbreak of the American Revolutionary War. Re-exported sugar might have contributed a further 1 to 2 per cent of GDP by the end of the period. By 1776, however, the sugar trade's contribution to British GDP seems to have reached something of a peak: in the following decades the trade's share of British GDP decreased.

The growth of the sugar trade was, naturally, a response to a growth in demand for sugar in Britain (and in markets for British re-exports). By the late $18^{\text {th }}$ century, per capita demand for sugar was certainly considerably higher in Britain than in other European nations. The growth of the sugar trade, then, indicates how growing purchasing power in Europe laid the foundation for what has been called the early modern "consumer revolution" (McKendrick et al. 1982; Stols 2004; De Vries 2008, p. 181; Rönnbäck 2010). At the same time, the increasing demand for the final product of the sugar commodity chain also created many economic opportunities for British agents, not least employment opportunities for various people working in all the sectors involved in the sugar commodity chain. The economic opportunities created in the sugar commodity chain could therefore be important for 
the economic development of Britain in a couple of different ways. Robert Allen has, for example, argued that the great demand for labour from British colonial shipping contributed substantially towards creating a high-wage economy in $18^{\text {th }}$-century Britain (Allen 2003, 2011). A high-wage economy, in turn, created incentives to innovate and substitute capital for labour through capital-intensive industrialisation (Allen 2009). It has furthermore been argued, by Acemoglu and co-authors, that Atlantic trade contributed to important institutional reforms in Britain, thereby laying the institutional foundation for British economic development (Acemoglu et al. 2005).

The sugar trade came to be an important part of many sectors of the British economy. The results of this paper have shown that the commodity chain was most important for the tertiary sector - particularly shipping, wholesaling, finance and insurance. By the late $18^{\text {th }}$ century, around 4 to 5 per cent of the total British GDP of the tertiary sector was directly associated with the sugar trade. This leg of the triangular trade, at least, therefore contributed most immediately to the development of the service sector in the British economy, not industrial development as Eric Williams once argued (Williams 1964 [1944], p. 105). Other parts of the economy, including the industrial sector, would, however, also stand to gain from the sugar trade through the many economic linkages to other parts of the economy. The demand for many services would in turn have repercussions on the secondary sector. One example of such economic linkages was shipbuilding, driven by the growing demand for freight shipping (Inikori 2002, Ch. 6). A related sector was the growth of the construction industry, driven by the investments in docks in port cities such as London (Draper 2008). Nuala Zahedieh has also recently shown how buoyant colonial demand for copper most importantly for the boiling of sugar - contributed not only to extensive growth in this industry, bringing it back from the dead, but also to much inventive activity in order to cut costs in copper production (Zahedieh 2013). Could the capital invested in the sugar commodity chain have been invested more profitably elsewhere? Previous scholars have largely discredited the argument that the slave trade provided any «super-profits», that is, very much higher profits than in other sectors of the economy, at least not in the $18^{\text {th }}$ century. The evidence does, however, show that the profits in those parts of the trade that have been studied previously were at least as high as in similarly risky investments elsewhere (Ward 1978; Daudin 2004; Daudin 2005).

\section{THE BRITISH SUGAR TRADE IN A COMPARATIVE PERSPECTIVE}

Most of the value adding economic activity of the commodity chain took place in Britain itself, or by British agents operating within the British Empire's overseas colonies. As has been shown in this paper, only a small share of the economic activity generated had few or no immediate repercussions for the British economy. The Caribbean planters only appropriated a small share 
(around a third) of all the value added in the sugar commodity chain — and even in this case quite a considerable share of their factor incomes were normally repatriated to Britain, either in the form of payments on borrowed capital, or as repatriated profits. The greatest share of the value added by the whole sugar commodity chain was, however, contributed not at the plantation level, but at the stages of wholesaling and refining the sugar in Britain. These results do not conflict with the conclusions of previous studies on the profitability and wealth of Jamaica and other Caribbean colonies (see, e.g. Sheridan 1965; Sheridan 1968; Thomas 1968; Coelho 1973; Ward 1978; Zahedieh 1986; Sheridan 1994 [1974]; Eltis 1995, 1997; Rönnbäck 2009, 2011). On the contrary, the estimates of the value added in the commodity chain show the great economic activity generated by sugar trade not only on the plantations, but also in many trades dependent on the sugar plantations - and not only in the Caribbean, but throughout the British imperial economy, including the industrial centres of Britain.

Britain was far from the only sugar producer in Europe. In some parts of Europe, for example, in the Netherlands and Germany, there were considerable investments in sugar refineries, largely or exclusively refining raw sugar imported from some other European nation's colonies in the Americas (Deerr 1949, Ch. 28). There were also several colonial powers involved in sugar production in the Americas. In the $18^{\text {th }}$ century, French production on Saint Domingue would, for example, grow rapidly. Most importantly, however, Portugal was the first European nation to start large-scale production of sugar, in colonial Brazil, and continued to be a major producer of sugar throughout the early modern period (Arruda 1991; Curtin 1998; Schwartz 2004; Daudin 2005; Ebert 2008). So far, there are no studies showing how important the $18^{\text {th }}$-century sugar commodity chain was relative to these economies, respectively, but it seems reasonable to assume that its importance was often quite substantial, at least in a case such as Portugal. Nonetheless, these nations Portugal perhaps in particular - saw little or nothing of the economic development that Britain experienced during the $18^{\text {th }}$-century Industrial Revolution. This shows clearly that the "contribution of the periphery" to European economic development must not be overemphasised. Active participation in colonialism and colonial trade was clearly not a sufficient factor for economic development. Many other factors were crucial to European economic development, including factors such as access to natural resources, institutions, capital accumulation and scientific progress, as emphasised by many previous scholars.

\section{CONCLUSION}

It has been shown in this paper that the contribution of the sugar commodity chain to British GDP increased from 1 per cent in the early $18^{\text {th }}$ century, to around 4 to 5 per cent by the end of the century. This contribution was most marked in the service sector. The growing demand for 
luxuries such as sugar was directly connected to a growth in living standards for a substantial share of the population of Britain at the time. This paper also argues that the trade in colonial sugar in turn generated non-negligible economic activity that opened up many economic opportunities for various agents. This had important repercussions on other factors such as the development of a British high-wage economy and institutional development. Sugar was, furthermore, just one of many colonial goods that were traded. In order to approach a more realistic assessment of the total economic value of colonial trade, we would also have to add the economic activity generated by other colonial trade goods, such as cotton, tobacco, coffee, dyestuffs and so on, as well as the heinous slave trade.

\section{REFERENCES}

Acemoglu, D.; Johnson, S., and Robinson, J. (2005): «The Rise of Europe: Atlantic Trade, Institutional Change, and Economic Growth». American Economic Review 95 (2), pp. 546-579.

AlEXANDER, D. (1970): Retailing in England during the Industrial Revolution. London: Athlone Press.

Allen, R. (2003): «Progress and Poverty in Early Modern Europe». Economic History Review 56 (3), pp. 403-443.

Allen, R. (2009): The British Industrial Revolution in Global Perspective. Cambridge: Cambridge University Press.

Allen, R. (2011): "Why the Industrial Revolution was British: Commerce, Induced Invention, and the Scientific Revolution». Economic History Review 64 (2), pp. 357-384.

Allen, R.; Bassino, J. P.; Ma, D.; Moll-Murata, C., and van Zanden, J. L. (2011): «Wages, Prices, and Living Standards in China, 1737-1925: In Comparison with Europe, Japan, and India». Economic History Review 64 (S1), pp. 8-38.

Allen, R.; Murphy, T., and Schneider, E. (2012): «The Colonial Origins of the Divergence in the Americas: A Labor Market Approach». Journal of Economic History 72 (4), pp. 863-894.

ARRUDA, J. J. DE A. (1991): «Colonies as Mercantile Investments: The Luso-Brazilian Empire, 1500-1808», in J. Tracy (ed.), The Political Economy of Merchant Empires: State Power and World Trade 1350-1750. Cambridge: Cambridge University Press, pp. 360-420.

Broadberry, S.; Campbell, B.; Klein, A.; Overton, M., and van Leeuwen, B. (2011): «British Economic Growth 1270-1870: An Output-Based Approach». LSE Working Paper, 18 December 2011. [Available online at http://hdl.handle.net/10871/13984].

CLARK, G. (2005): «The Condition of the Working Class in England, 1209-2004». Journal of Political Economy 113 (6), pp. 1307-1340.

Coelho, P. (1973): «The Profitability of Imperialism: The British Experience in the West Indies 1768-1772». Explorations in Economic History 10 (3), pp. 253-280.

CuRTin, P. (1998): The Rise and Fall of the Plantation Complex: Essays in Atlantic History, 2nd edn. Cambridge: Cambridge University Press.

DAudin, G. (2004): «Profitability of Slave and Long-Distance Trading in Context: The Case of Eighteenth-Century France». Journal of Economic History 64 (1), pp. 144-171.

Daudin, G. (2005): Commerce et Prosperité. La France au XVIIIe siècle. Paris: PUPS.

Davis, R. (1979): The Industrial Revolution and British Overseas Trade. Leicester: Leicester University Press. 
DeErr, N. (1949): The History of Sugar. London: Chapman and Hall.

de VRIES, J. (2008): The Industrious Revolution: Consumer Behavior and the Household Economy, 1650 to the Present. Cambridge: Cambridge University Press.

Domar, E. (1970): «The Causes of Slavery or Serfdom: A Hypothesis». Journal of Economic History 30 (1), pp. 18-32.

DraPer, N. (2008): "The City of London and Slavery: Evidence from the First Dock Companies, 1795-1800». Economic History Review 61 (2), pp. 432-466.

Dunn, R. (1972): Sugar and Slaves. The Rise of the Planter Class in the English West Indies, 1624-1713. New York: W.W. Norton.

EBERT, C. (2008): Between Empires: Brazilian Sugar in the Early Atlantic Economy, 1550-1630. Leiden: Brill.

Eltis, D. (1995): «The Total Product of Barbados, 1664-1701». Journal of Economic History 55 (2), pp. 321-338.

Eltis, D. (1997): "The Slave Economies of the Caribbean: Structure, Performance, Evolution and Significance», in F. Knight (ed.), General History of the Caribbean. Vol III: The Slave Societies of the Caribbean. Paris: UNESCO, pp. 105-137.

Engerman, S. (1972): «The Slave Trade and British Capital Formation in the Eighteenth Century: A Comment on the Williams Thesis». Business History Review 46 (4), pp. 430-443.

Engerman, S., and Solow, B. (1987): British Capitalism \& Caribbean Slavery. The Legacy of Eric Williams. Cambridge: Cambridge University Press.

Findlay, R., and O'Rourke, K. (2007): Power and Plenty: Trade, War, and the World Economy in the Second Millennium. Princeton: Princeton University Press.

Galloway, J. H. (1989): The Sugar Cane Industry: A Historical Geography from its Origins to 1914. Cambridge: Cambridge University Press.

Harley, C. K. (2013): Slavery, the British Atlantic Economy and the Industrial Revolution. Oxford Discussion Papers in Economic and Social History no. 113, University of Oxford.

Higman, B. W. (1996): «Patterns of Exchange Within a Plantation Economy: Jamaica at the Time of Emancipation», in R. McDonald (ed.), West Indies Accounts. Essays on the History of the British Caribbean and the Atlantic Economy in Honour of Richard Sheridan. Barbados: University of West Indies Press, pp. 211-231.

Higman, B. W. (2000): "The Sugar Revolution». Economic History Review 53 (2), pp. 213-236.

Hopkins, T., and Wallerstein, I. (1986): «Commodity Chains in the World Economy Prior to 1800». Review (Fernand Braudel Center) 10 (1), pp. 157-170.

INIKORI, J. (2002): Africans and the Industrial Revolution in England. A Study in International Trade and Economic Development. Cambridge: Cambridge University Press.

Kolchin, P. (1987): Unfree Labor. American Slavery and Russian Serfdom. Cambridge: Harvard University Press.

McCloskey, D. (2010): Bourgeois Dignity: Why Economics Can't Explain the Modern World. Chicago: University of Chicago Press.

McCusker, J. (1970): The Rum Trade and the Balance of Payments of the Thirteen Continental Colonies, 1650-1775. University of Pittsburgh, thesis.

McCusker, J., and Menard, R. (1985): The Economy of British America 1607-1789. Chapel Hill: University of North Carolina Press.

McKendrick, N.; Brewer, J., and Plumb, J. H. (1982): The Birth of a Consumer Society The Commercialization of Eighteenth-Century England. London: Europa Publications.

McNeill, J. (2010): Mosquito Empires: Ecology and War in the Greater Caribbean, 16201914. Cambridge: Cambridge University Press.

Menard, R. (1991): "Transport Costs and Long-Range Trade, 1300-1800: Was there a European «Transport Revolution» in the Early Modern Era?», in J. Tracy (ed.), 
The Political Economy of Merchant Empires. State Power and World Trade 1350-1750. Cambridge: Cambridge University Press, pp. 228-275.

Menard, R. (2006): Sweet Negotiations. Sugar, Slavery and Plantation Agriculture in Early Barbados. Charlottesville: University of Virginia Press.

Mintz, S. (1985): Sweetness and Power. The Place of Sugar in Modern History. New York: Penguin.

Morgan, K. (1993): Bristol and the Atlantic Trade in the Eighteenth Century. Cambridge: Cambridge University Press.

Morgan, K. (2000): Slavery, Atlantic Trade and the British Economy, 1660-1800. Cambridge: Cambridge University Press.

Moya Pons, F. (2007): History of the Caribbean. Princeton: Markus Wiener Publishers.

O'Brien, P. (1982): "European Economic Development: The Contribution of the Periphery». Economic History Review 35 (1), pp. 1-18.

O'BRIEN, P. (2006): "A Critical Review of a Tradition of Meta-Narratives of Global Economic History from Adam Smith to Ken Pomeranz», in P. Emmer (ed.), Atlantic Colonial Trade and European Economic Development. Leiden: Brill.

Price, J. (1991): «Credit in the Slave Trade and Plantation Economies», in B. Solow (ed.), Slavery and the Rise of the Atlantic System. Cambridge: Cambridge University Press.

Ryden, D. B. (2009): West Indian Slavery and British Abolition, 1783-1807. Cambridge: Cambridge University Press.

RönNBÄcK, K. (2009): «Who Stood to Gain from Colonialism: A Case-Study of EarlyModern European Colonialism in the Caribbean». International Journal on the History of European Expansion and Global Interaction 33 (3), pp. 135-154.

RönnBÄCK, K. (2010): "An Early Modern Consumer Revolution in the Baltic?». Scandinavian Journal of History 35 (2), pp. 177-197.

RönnBäcK, K. (2011): «Power, Plenty and Pressure Groups: A Comparative Study of British and Danish Colonialism in the West Indies and the Role of the State, 1768-1772». Journal of Early American History 1 (3), pp. 215-240.

Schwartz, S. (ed., 2004): Tropical Babylons: Sugar and the Making of the Atlantic World, 1450-1680. Chapel Hill: University of North Carolina Press.

SHERIDAN, R. (1965): "The Wealth of Jamaica in the Eighteenth Century». Economic History Review 18 (2), pp. 292-311.

SHERIDAN, R. (1968): «The Wealth of Jamaica in the Eighteenth Century: A Rejoinder». Economic History Review 21 (1), pp. 46-61.

SHERIDAN, R. (1994 [1974]): Sugar and Slavery. An Economic History of the British West Indies, 1623-1775. Kingston: Canoe Press.

Solow, B. (ed., 1991): Slavery and the Rise of the Atlantic System. Cambridge: Cambridge University Press.

Solow, B., and Engerman, S. (eds., 1987): British Capitalism \& Caribbean Slavery: The Legacy of Eric Williams. Cambridge: Cambridge University Press.

Stein, R. L. (1988): The French Sugar Business in the Eighteenth Century. Baton Rouge: Louisiana State University Press.

Stern, W. (1954): «The London Sugar Refineries Around 1800». The Guildhall Miscellany 3, pp. 25-36.

Stinchсомве, A. (1995): Sugar Island Slavery in the Age of Enlightenment. The Political Economy of the Caribbean World. Princeton: Princeton University Press.

SтоLS, E. (2004): "The Expansion of the Sugar Market in Western Europe», in S. Schwartz (ed.), Tropical Babylons: Sugar and the Making of the Atlantic World, 1450-1680. Chapel Hill: University of North Carolina Press, pp. 237-288. 
SveistruP, P.P., and Willerslev, R. (1945): «Den Danske Sukkerhandels og Sukkerproduktions Historie [The History of the Danish Sugar Trade and Sugar Production]». Copenhagen: Institutet for Historie og Samfundsøkonomi.

Thomas, R. P. (1968): «The Sugar Colonies of the Old Empire: Profit or Loss for Great Britain?». Economic History Review 21 (1), pp. 30-45.

TopiK., S.; MarichaL, C., and Frank, Z. (eds., 2006): From Silver to Cocaine: Latin American Commodity Chains and the Building of the World Economy, 1500-2000. Durham: Duke University Press.

WARD, J. R. (1978): "The Profitability of Sugar Planting in the British West Indies, 1650-1834». Economic History Review 31 (2), pp. 197-213.

Watts, D. (1987): The West Indies. Patterns of Development, Culture and Environmental Change Since 1492. Cambridge: Cambridge University Press.

Williams, E. (1964 [1944]): Capitalism and Slavery. London: Andre Deutsch.

Woloson, W. (2002): Refined Tastes: Sugar, Confectionery, and Consumers in NineteenthCentury America. Baltimore: Johns Hopkins University Press.

Zahedien, N. (1986): «Trade, Plunder, and Economic Development in Early English Jamaica, 1655-89». Economic History Review 39 (2), pp. 205-222.

ZAHEDIEH, N. (2013): «Colonies, Copper, and the Market for Inventive Activity in England and Wales, 1680-1730». Economic History Review 66 (3), pp. 805-825.

\section{APPENDIX A: DISAGGREGATING THE VALUE ADDED IN THE SUGAR COMMODITY CHAIN}

\section{A1. Disaggregating the Value Added at the Plantation Stage \\ Subsistence cost for slaves}

J. R. Ward reports data on the subsistence costs for slaves on Caribbean plantations (Ward 1978). Unfortunately, the data only cover a few years at the end of the $18^{\text {th }}$ and the early $19^{\text {th }}$ centuries (1799-1834). It is also unclear how many observations the tables are based on. Ward is also the first to acknowledge the potential problem of bias in his sample. There is a fairly recent trend to estimate the historical cost of a subsistence basket of goods from various places in the world, including Latin America (Allen 2009; Allen et al. 2012). To the knowledge of this author, no similar studies have so far been undertaken for the Caribbean. To the extent that the Caribbean colonies were dependent on imported foodstuffs, we can perhaps expect the prices to have been higher during the French Revolutionary and Napoleonic Wars than they were in peacetime. I have therefore deflated the cost of living estimated by Ward for the last years of the $18^{\text {th }}$ century by the price of sugar on the local market, assuming that the prices of other foodstuffs roughly followed similar price trends as sugar did at the time.

\section{Productivity of slaves}

In order to calculate the cost of subsistence wages per volume of sugar produced, we need to know the productivity of the workers. Recent estimates 
of the physical productivity of a Caribbean slave working in the sugar plantations have been produced by David Beck Ryden (2009, figure 9.2).

\section{Plantation gross surplus}

The gross surplus at the plantation is calculated as the residual of value added after subtracting the cost of paying for the subsistence needs of the slaves. In order to estimate the profits of plantations, data on capital employed would be required. This information can be found in J. R. Ward's study (Ward 1978). The data are not annual, but summed over specific periods of time.

\section{A2. Disaggregating the Value Added at the Wholesale Stage}

\section{Loss in transit}

Some of the raw sugar exported from the Caribbean was lost in transit, for example, owing to leakage from the hogsheads that the raw sugar was transported in. Estimates of the losses vary from around 12 to 25 per cent of the volume shipped from the Caribbean (McCusker 1970, pp. 138-142; Sheridan 1994, p. 44). It is assumed here that average losses amounted to 20 per cent of the exports.

\section{Transport and transaction costs}

Ward reports data on insurance fees, freight rates and commissions for traders in sugar (Ward 1978, tables 1-2, p. 199; see also Menard 1991, table 6.6 for alternative freight rates). Insurance and commission fees were both quoted as a percentage of the price of the sugar, whereas freight rates were quoted per weight (cwt). These data then enable us to calculate the c.i.f. price (cost, insurance and freight) of the sugar once in England.

\section{Duties}

Data on the English import duties on sugar can be found in Noell Deerr's study of the history of sugar (Deerr 1949, vol. II, p. 430). The duty figures used are for "home muscovado» sugar, that is, muscovado sugar arriving from some British colony.

\section{Wholesale gross surplus}

There are so far no data available on the gross surplus in the wholesale trade. This is therefore treated as the residual of the value added, after subtracting all other factors that contribute to the value added at this stage of the commodity chain. 


\section{A3. Disaggregating the value added at the refinery stage}

\section{Refining}

Disaggregating the value added at the stage of refining is problematic for the simple reason that, perhaps somewhat surprisingly, there has been rather little research into the economics of the early modern sugar refineries in Europe. The little quantitative research carried out so far is concerned with Danish sugar refineries of the $18^{\text {th }}$ century. From this research, we know that there was quite a steady, linear relationship between the number of workers at the sugar refinery and the final value of production. This indicates that there were very limited economies of scale or scope, and that if there were any technological differences between smaller and larger factories, they had a limited impact on labour productivity (Sveistrup and Willerslev 1945, table 34). From the Danish sources, it is also possible to make a crude calculation of some of the factor incomes of the largest sugar factory, owned by the Schimmelmann family.

Given that it was quite a capital-intensive industry for the time, the share of the added value contributed by workers was fairly small, only around 5 per cent. Fuel costs made up some 5 to 10 per cent of the value added, whereas "other costs» (presumably including costs of capital, etc.) varied considerably, between 20 and 50 per cent of the value added. The net profits that the owners of the Schimmelmann sugar refinery could thus pocket also varied widely, but in both years for which we have data constituted a considerable share - some 40 to 70 per cent - of the value added at the refinery. The rate of surplus value was also extremely high, at several hundred per cent.

Can we assume that the British refineries experienced a similar situation? Only a handful of competing sugar refineries existed in Denmark at the time (seventeen in total, Sveistrup and Willerslev 1945). The Danish market for sugar was, on the other hand, much smaller than the British in the $18^{\text {th }}$ century owing to both a smaller population, and a lower per capita consumption of sugar (Rönnbäck 2010). At the same time, previous scholars have argued that the British market was highly protected from foreign competition (Coelho 1973). We can therefore not assume $a$ priori that the Danish market was less competitive than the British. In fact, the mark-up ratio between the wholesale and retail prices of sugar was on average around 80 per cent in the English market, but only 50 to 75 per cent in the Danish refineries (calculations based on data underlying Figure 1 for English prices, and on data in Table A1 for the Danish prices).

\section{Retailing}

Starting at the end of the commodity chain, the refined sugar reached the consumer by way of various retailers. In his study of retailing during the Industrial Revolution, David Alexander has found that the mark-up on the price of groceries in general was comparatively low - between 5 and 
TABLE A1

FACTOR INCOMES AT THE SCHIMMELMANN SUGAR FACTORY, 1792 AND 1801

\begin{tabular}{|l|c|c|c|c|}
\hline & \multicolumn{2}{|c|}{$\begin{array}{c}\text { Costs/profits per year } \\
\text { (rigsdaler) }\end{array}$} & \multicolumn{2}{c|}{$\begin{array}{c}\text { Share of value added } \\
\text { (per cent) }\end{array}$} \\
\hline & $\mathbf{1 7 9 2}$ & $\mathbf{1 8 0 1}$ & $\mathbf{1 7 9 2}$ & $\mathbf{1 8 0 1}$ \\
\hline Raw sugar purchases & 202,954 & 241,806 & & \\
\hline Labour costs & 7,500 & 7,500 & 5 & 6 \\
\hline Fuel costs & 4,650 & 4,650 & 11 & 6 \\
\hline Other costs & 31,918 & 60,774 & 21 & 51 \\
\hline Returns to capital & 105,792 & 46,362 & 71 & 39 \\
\hline
\end{tabular}

Source: Calculations based on Sveistrup and Willerslev (1945, table 45, pp. 80-81).

10 per cent - in the early $19^{\text {th }}$ century (Alexander 1970, table 6.1). Anecdotal evidence from this time also suggests that sugar was often used as a catchpenny to attract customers into grocery stores, so it is uncertain if the mark-up on sugar in particular was even this high (Alexander 1970, pp. 113, 170-171). In this paper, I have assumed that the retail price of sugar included a 5 per cent mark-up on the price from the refinery.

\section{APPENDIX B: THE WEIGHTED PRICE OF REFINED SUGAR IN BRITAIN}

Once in Europe, most of the imported sugar was brought to a sugar factory or refinery in order to further purify the product to a quality attractive to consumers. A number of different qualities were sold on the final market refined sugar, canary sugar, candy sugar, lump sugar and so on - to a large extent targeting different groups of consumers. Figure B1 shows the price of some of the most common varieties of sugar.

As can be seen in the figure, the prices of many different qualities of sugar are highly correlated (around 95 per cent correlation in the case of some of the most highly refined varieties of sugar). An important by-product from the process of refining was treacle, which could also be sold on the market (but at a price even lower than that of raw sugar). The value of the output from the refinery was therefore highly dependent on how much of the highly priced varieties of sugar that the refinery was able to produce from the input, and how much went to "waste» or ended up in the form of cheap treacle. Data from London refineries around the year 1800 indicate that around half of the input was converted into more highly priced varieties («refined sugar» or better), 20 per cent became sugar of some cruder variety, 25 per cent of the original input ended up as the by-product of treacle and 5 per cent went to waste (Stern 1954, p. 29). Figures on 
FIGURE B1

THE PRICE OF REFINED VARIETIES OF SUGAR IN ENGLAND, 1700-1807

(SHILLINGS/KG, DEFLATED), INCL. WEIGHTED PRICE OF OUTPUT FROM REFINERY

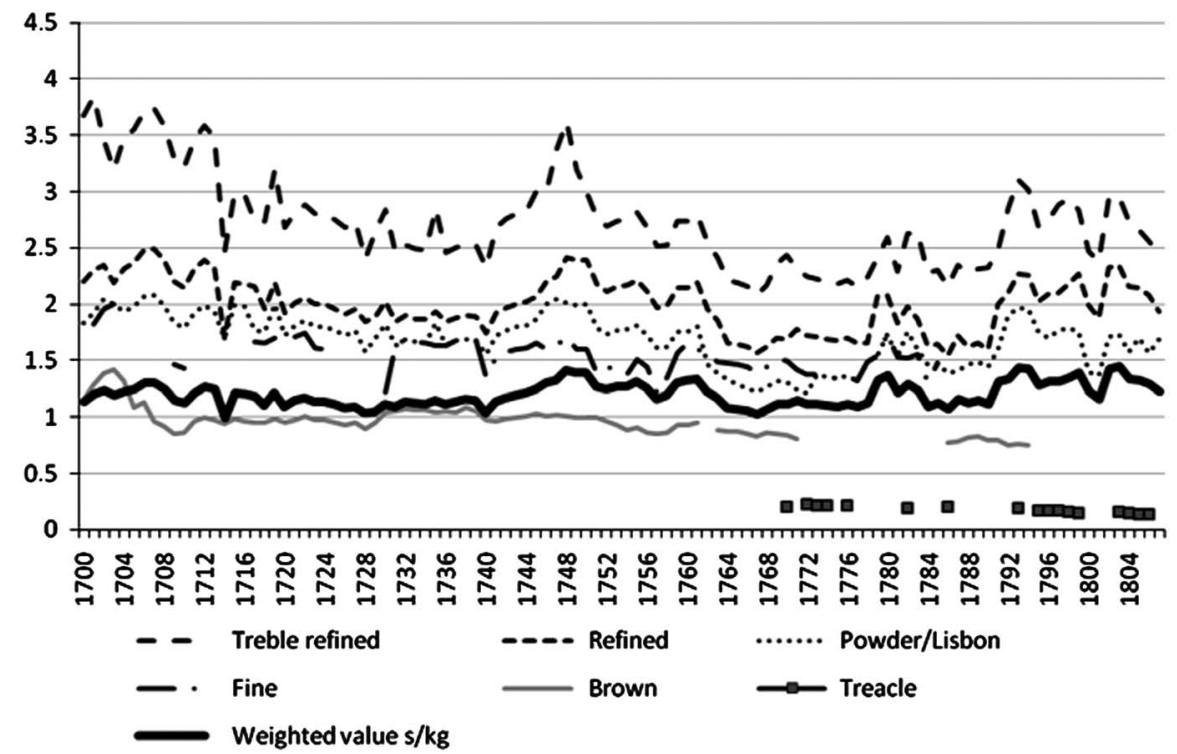

Source: Data set underlying Clark (2005). Price deflator $(1,700=100)$ from database underlying Broadberry et al. (2011).

Note: The weighted price series is calculated as a weighted average of the price of refined sugar ( 50 per cent), fine sugar ( 20 per cent), treacle ( 25 per cent) and a certain amount ( 5 per cent) of the raw sugar going to waste, reflecting the output of sugar refineries in London around 1800 (Stern 1954, p. 29).

output from French refineries indicate that there might have been an improvement in production techniques, increasing the ratio of the valuable refined sugar over time. Traditionally, perhaps around half of the raw sugar could be converted into various sorts of refined sugar. By the 1780 s and 1790 s, however, $\sim 70$ per cent of the input of raw sugar could be transformed into various forms of refined sugar. In experimental trials, the ratio could even be increased to around 80 per cent of the input transformed into refined sugar, but it is uncertain if this high ratio could ever become operational on a large scale (Stein 1988, Ch. 7). In this paper, I have assumed that there was an improvement in production techniques in British refineries as well. A first benchmark, from the beginning of the $18^{\text {th }}$ century, is therefore assumed to have been equivalent to the traditional French output figures (around 50 per cent refined sugar). The figure from London refineries in the year 1800 is used as a second benchmark. Data are interpolated for the years in between. This allows for the calculation of a weighted series for the value of the output from the refineries (see dashed line in Figure B1). 